\title{
MEDICOLEGAL STUDY OF HOMICIDE BY FIREARMS AND EXPLOSIVES
}

Rajeev Kumar ${ }^{1}$

\section{HOW TO CITE THIS ARTICLE:}

Rajeev Kumar. "Medico-legal study of homicide by firearms and explosives". Journal of Evolution of Medical and Dental Sciences 2013; Vol. 2, Issue 44, November 04; Page: 8490-8507.

ABSTRACT: BACKGROUND: Though homicide, in general seems universal, the type and pattern are specific to particular societies and particular times. OBJECTIVE: Medicolegal study of homicide by firearms and explosives. METHODS: The present study comprised of 100 (one hundred) cases of homicidal firearms and explosives deaths drawn from the medicolegal autopsies held in the mortuary of the department of Forensic Medicine accompanied by sufficient number of relevant persons who were thoroughly interviewed at the time of autopsy on the body of deceased victim of homicide by firearm and explosives. RESULTS: It was found that in max (40\%) victims shot gun was used followed by countrymade firearms $21 \%$, rifel $14 \%$, revolver $12 \%$,bombs $12 \%$,Pistol was used in $10 \%$ and AK47 rifle was used in $2 \%$ Victims. Over majority (77\%) of victims were not hospitalized. Very less no of victims 13\% were hospitalized but not operated.Few Victims 10\% were hospitalized and operated. Over majority $55 \%$ of victims died at the scene of crime followed by $23 \%$ Victims who died following admission into th hospital.Only few 5\% victims died on way to the hospital.In $17 \%$ victims place of death could not be known. In $43 \%$ of victims death was instanlaneous.Victims survived for less than one $\mathrm{hr}$ in $13 \%$ followed by, $1 \mathrm{hr}$ to $6 \mathrm{hr} 6 \%, 6 \mathrm{hr}$ to $24 \mathrm{hr} 3 \%$ and more then 24 hrs $18 \%$.Survival period in $17 \%$ victims could not be ascertained as only dead body was recovered.It was found that that max $43 \%$ victims died instantan eously due to injuries to vital organ (s) followed by death due to shock and haemorrhage $25 \%$, septicaemia $14 \%$,Coma $12 \%$,blast lungs $4 \%$ and asphyxia due to aspiration of blood in the respiratory tract. In max no $61.36 \%$ of victims, single weapon was used followed by used of double weapon in $14.78 \%$ and in vary few victims $4.54 \%$ more than two weapon were used. However, in $19.31 \%$ victims it could not be known. In $46.59 \%$ victim, location of entry wound was on multiple body parts followed by on head $40.90 \%$, chest $27.27 \%$, abdomen $7.95 \%$,neck $2.27 \%$,Upper extremity $2.27 \%$,lower extremity $1.13 \%$.In majority $53.40 \%$ of the victims had one entry wound followed by two in $15.90 \%$, three \%, and more then Three 19.31\%.Findings on range of firearm discharge clearly depict that max no of victims (40.90\%) of homicide by firearm, were shot at from close/Near range.This was followed by contact wound in $29.54 \%$ and distat range in $20.45 \%$.Combination of near and distant range was seen in 9.09\%.It was found that in three fourth (75\%) victims there were no associated injuries by any weapon other than firearm.In only $2(2.27 \%)$ Victims associated fatal injuries were present.However, in as many as $20(22.75 \%)$ victims associated injuries by other weapons were present but they were not fatal. CONCLUSION: Over three fourth of the victims of homicide by firearms die on the spot due to injuries to vital organs followed by shock and hemorrhage.

KEY WORDS: Medicolegal, homicide.

INTRODUCTION: Homicide may be due to certain provocation on the part of the victim and / or uncontrollable impulsive emotion of the murderer, but impulsive behaviour does not force everybody to commit criminal homicide. Every murderer, therefore, gradually and consciously or unconsciously accepts homicide as an absolute solution for problem he faces. Though homicide, in 


\section{ORIGINAL ARTICLE}

general seems universal, the type and pattern are specific to particular societies and particular times.

The criminal- victim relationship is called 'Victimology' and considered as an integral part of criminology (Devasis and Devasia, 1989). Victim is not just a passive object but an active component of his or her own victimization. Victimology is the empirical, factual study of victims of crime and as such is closely related to criminology, and thus may be regarded as a part of the general problem of crime. In a broader sense Victimization and the efforts of society to preserve the rights of the victims.

In India according to the probation of offenders Act, 1958. the court has power to ask released offenders to pay compensation and costs: " (a) Such compensation as the court thinks reasonable for loss or injury caused to any person by the commission of the offence; (b) such costs of the proceeding as the court thinks reasonable" (section 5). Hence restitution to victims is considered as a major element of punishment besides the protection of law and order and the reformation and rehabilitation of the criminal Restitution to victims is based on two components e.g. obligation of the offender and obligations of the society.

The financial position of the offender generally determines whether the victim will receive restitution. It is argued that when the state fails to fulfil its basic responsibility of furnishing safety measure and security to its citizens, the state is morally responsible for the suffering inflicted upon the victim.

The concept "Prevention is better than cure" is not only applicable to medicine discipline; but is equally useful in dealing with the social disease; which can be prevented.

Kern and Mc Corkle (1963) defines "crime prevention as any effort that tends to reinforce society control over its members". According to them, it includes the activities such as: (1) to prevent a crime from succeeding (2) to prevent the development of criminal motivation (3) to facilitate the channeling to motives in legitimate direction and (4) to prevent the development of criminal opportunities. Generally, crime prevention means the steps and efforts taken to control the occurrence of crime incidence.

Educational institutions play a big role in developing and moulding the character of future citizens. But now-a-days, teachers thinks their job is to teach the subject only, and they rarely participate in the character development of their students. Besides teachers never set them as examplers. This may be the reason why students also exhibit violent activities and turn as deviants. Hence, teacher should change themselves and try to mould the character of students.

The violent and gang activities are to the absence of proper value system among human beings religion, as a strong control agency, can prevent its members from violent activities.

Rao says that all crime prevention programme should be based on realistic combination of both the element of deterrence and reformation. Deterrence and punishment are meant to prevent the criminal from repeating the (B.P.R.D., 1983).

Public participation in crime prevention is good step. In villages men directly or indirectly participate and try to control the crime incidents. But in cities, even if they see a crime incident, they see it and leave the place immediately. They feel witnessing such incident may endanger them; and they fear for the legal proceedings and other difficulties in attending court and police station. Hence, rarely people come forward to help the law enforcement agencies. In this connection, it is strongly 
suggested that sufficient changes in legal proceedings should be made, so that public may also participate in prevention of crime.

Another way to participate in crime prevention programme is involvement through crime prevention organization. At present, there is a national level voluntary organization called as All India Crime Prevention Society. At the state and District level also crime prevention societies can be Organized; through such societies, through which educational and other crime prevention programmes can be organized (B.P.R.D.) 1983).

Clifford (1982) said "crime is normal feature of our social and economic life which can be fostered or contained by the action of the community, crime can be prevented or promoted by the way we do our planning nationally, regionally, locally or in our cities. Therefore proper planning at all level prevents and control crime rate.

Clarke (1983) has proposed an opportunity theory of crime prevention. He had argued that crime are often committed because of the opportunities Presented by the environment for commission of those crimes, if these Opportunities are reduced, then the rate with which these crime are committed will be reduced.

The situation and pattern of crime in India has become more serious. The socio-economic and political system is generally regarded as responsible for present deteriorating crime situation.

The crime generally have been classified in adult and non adult or non juvenile group. The number of both crime have been found increasingly growing at a high growth rate since independence.

REVIEW OF LITERATURE: Gartner (1990) studied regarding the temporal and cross-national comparison of the victim of homicide from 18 developed countries and found that homicide rates was 60 per cent higher in the end 1970's in comparison to late 50's in different field in different countries (WHO varies years). In the above study the main participants countries were Australia, New Zealand, Italy, Switzerland, Norway, Finland, U.S.A and Canada. That provided the recent cross national difference in homicide rate that is really directly associated with structural's and cultural environment and homicide rate varies in accordance with sex and age. As it was studied, it was found in U.S.A. where young adult men were more in comparision to female and children and homicide rates were higher in adults due to economic inequalities whereas in children's it was not the same.

Fanslow et al.(1995) were specially concerned with the problem of homicide in New zealand. They observed the mortality rate from homicide for 10 years period was 1.6 per 100,000 persons per year and a significant increase in the rate of homicide was identified. The rate of males were higher (2.0) than those for female (1.2), with those within 20 to 24 years of age mostly at risk. The data also shows homicide were most likely to occur on Friday or Saturday Between the hours of 6 $\mathrm{PM}$ and $6 \mathrm{AM}$. In 55 per cent of homicides, the victim and assailants were known to each other.

The adequate documentation of the crime and murder rate may reveal that its nature and extent may increase manifold in view of the socio-cultural, economic and political change taking place around the world, from the beginning of the 19th century, statistics enable us to trace the course of criminality. The latter has increased everywhere. In France the increase in nearly 300 per cent (Coser, 1964). 
The data compiled in the united nations reveals that the level of homicide does very form society to society. The available data shows the united states with a rate of 9-10 per 100,000 population continues to rank first among highly industrialized countries, while some of the south America countries, Columbia, Mexico and Nicaragua are reporting a staggering high annual rate between 20 and 25 per 100,000 for the last many years. Among other south America societys, Venezuela had a rate of 9.0, Peru 4.7 and Chile 2.3 in recent years. In most of western European societies rates have been found to be consistently lowest with Austria, Bulgaria, England and wales less then 1.0, Greece 0.7, Norway 0.6, Switzerland 1.0 and Denmark, France,Italy, Netherlands, Portugal, Sweden, Spain, and west Germany between 1.0 and 2.0 and among the communist countries of Bulgaria 2.3, Czechoslovakia 2.1, Hungry 2.0 and Poland 0.9. In Asia, Thailand has been reporting the highest annual rates of 20.0 per 100,000 population, while japan had 1.0, Philippines 2.0 and India 3.0. The rate for Canada had been between 2 and 3, for Australia 1.9 and New Zealand 0.8. The recent study of swiss cities reveals that there is little crime in the cities, which had dispelled the stereotype image of cities as the main generators of higher rates of crime (Nag Paul, 1985).

DIMENSION OF THE PROBLEM: Firearms are one of the most lethal weapons of the present day society and its use in crimes and violence is increasing. Out of 588 homicidal victims Studied by Wolfgang (1958) in Philadelphia shooting accounted for 33\% of the Cases. 38\% were caused by stabbing and $5.9 \%$ by beating.

Analysis of 1111 in dictable of violence in1950 in London only 17 (1.5\%) involved the use of firearms, while 44 (2.4\%) of the same type of crime fell into this category in 1957 (MeClintock, 1963).

A study of 425 criminal homicide in Houston revealed that shooting accounted for $63.5 \%$, stabbing $25.4 \%$ and beating for $5.9 \%$ cases (pokorny, 1965).

Frank Zimring (1968) studied 510 homicide victims in chicano in 1966 found that firearms were used in $52 \%$ and knives in $30 \%$ of the cases. He again more or less the same pattern i.e guns in $57 \%$ and knives in $25 \%$ of the cases out of 533 homicides in 1969 also.

Rechard Block (1975) in his study of criminal homicides in Chicago from 1965 to 1973, found a steadily increasing use of firearms as weapons i.e. 50\% in 1955, 52\% in 1966, 69\% in 1972 and $71 \%$ in 1973.

Parts of Body Injured: In their series of 274 cases of homicide by firearms, Gonzales et al (1954) reported that $25 \%$ had been shot in the abdomen, $23 \%$ in the chest and only $10 \%$ in the head $7 \%$ were shot in the spine, $3 \%$ in the neck and $2 \%$ over the extremities. In the remaining $30 \%$ more than one bullet was encountered.

Frank Zimsing (1968) analysed 34 homicidal firearm deaths and showed that $44 \%$ involved the chest, $18 \%$ abdomen $32 \%$ head, while $3 \%$ involved back and shoulders.

Fattch et al. (1974) found that out of the 741 cases of firearm deaths, wounds in the chest (front and back) were in 383 (51.2\%) cases, it was the head and neck in 179 (24.2\%) cases and over the abdomen, extremities and buttocks respectively in 123 (16\%), 13 (1.9\%) and $3(0.4 \%)$ cases. In $40(5.4 \%)$ cases the total wounds were inflicted at more than one of the above sites.

In a series of 82 cases of homicidal firearm deaths studies by Gupta et al. (1979) it was found that entry wounds were located in front in 49 cases and on back in cases and over the sides in 10 
cases. Entry wounds were located in head and neck in 18 cases, 30 in chest, 21 in abdomen and 13 in upper and lower extremities. Than study al so revealed that in 29 instances pleura and lungs were involved, pericardium and heart in 25 cases, liver in 20 cases, stomach and intestines in 26 and brain and meanings were involved in 4 cases.

Das Gupta et al. (1983) study at Varanasi comprising 372 homicidal victims found that in $133(35.75 \%)$ cases head and neck were affected, upper extremity in $56(15.05 \%)$ and lower extremity in $87(23.38 \%)$ of cases. They al so found that heart and aorta were injured in $54(14.54 \%)$ victims, lungs in 76 (20.43\%), liner. Kidney, spleen, GIT and abdominal aorta in 98 (26.35\%) and there were multiple injuries over the body in 27 (7.25\%) cases.

Number of Shots Fired: In their series of 274 cases of homicide by firearms, Gonzales et al. (1954) reported that the majority were shot with a single shot. There were only 4 victims having multiple shots.

In 82 cases of firearm fatalities studied by Subrahmanyam et al. (1978), there was only one entry wound in $40(4078 \%)$ cases, two in 13 (15.85\%), three in $5(6.09 \%)$ cases and more than three entry wounds in $24(29.26 \%)$ cases. In a series of 82 case of homicidal firearm deaths studies by Gupta et al. (1979) these was only one entry wound in 32 (35.95\%) cases, two in $26(29.21 \%)$, three in 14 (15.73\%) cases and more than wound in $10(11.23 \%)$ cases.

Type of Weapon: Fattch et al. (1974) found that out of 1006 homicidal firearm deaths, shotguns were used in 164 (15.3\%) cases, pistols in 199 (19.2\%), rifles in 63 (7.5\%) and a pistol or rifle in 278 (22.8\%) cases. A 22 calibre pistol and rifle and a 12 bore shotgun were the commonly used weapons for homicidal proposes.

Of the 82 cases of firearm fatalities studied by Subrahmanyam et al. (1978), shotguns were used in $34(41.7 \%)$, revolvers in $19(23.2 \%)$ and rifles in $6(7.3 \%)$ of cases, while the nature of the weapon used could not be ascertained in 14 (16.9\%) cases.

Gupta et al. (1972) studied 82 homicidal firearm deaths and found that $43(52.43 \%)$ cases were killed by the shotguns, $11(13.4 \%)$ by rifles, $8(9.75 \%)$ by revolvers, $5(6 \%)$ by pistols), 3 (3.65\%) each by muskets and country made guns and the remaining $9(10.97 \%)$ cases by a combination of revolver and shotguns.

Range of Fires: Subrahmanyam et al. (1978) in their series of 82 cases observed that the victims were shot at close range in $38(46.3 \%)$ instances, it was a distant shot in $3(3.6 \%)$ cases, while a solitary victims was shot at contact range. The distance or range of fire could not be ascertained in as many as $40(48.8 \%)$ cases.

Out of the 82 homicidal firearm studied by Gupta et at. (1979), 45 (54.87\%) were from close / near range, 35 (42.68\%) from distant range and 2 (2.43\%) cases were shot from contact range.

\section{MATERIAL AND METHODS:}

Material: The present study comprised of 100 (one hundred) cases of homicidal firearms and explosives injuries drawn from the medicolegal autopsies held in the mortuary of the department of Forensic Medicine, Institute of Medical Sciences, Banaras Hindu University, Varanasi, U.P., India, during the period from 1st July 1999 to 30th Nov. 2000, accompanied by sufficient number of 
relevant persons who were thoroughly interviewed at the time of autopsy on the body of deceased victim of homicide by firearm and explosives.

For the study relevant questionnaires schedule were prepared to collect various data, data about incidence of fatal firearm and explosive death, data about medicolegal crime investigation and evidential data etc. These cases were studied for medicolegal aspects.

Methods :

The various data relating to the cases were collected from sources as under :

a. examination of inquest reports and connected papers.

b. interviewing the police personnel accompanying the cases.

c. interviewing the relatives, friends and neighbors of the deceased, and

d. the autopsy examination paper.

The various data pertaining to each case was collected by the methods as indicated above so as to provide information on the following points :

\section{History as regards date, time and place}

$A$ in Regard of Firearm and Explosives Involved

a. Type of shot gun (single/double) rifle, revolver, pistol country made Explosives: Disruptive/Blast effect/Burn

b. Number of weapons used,

c. How many shots were fired.

\section{B. Environmental Data}

a. Date and time of incidence

b. Place of incidence

(i) Indoor

(ii) Outdoor

c. Whether empty cartridge, shots, pellets etc. were recovered from the scene.

\section{A. Nature of firearm and explosive injuries and the related findings were obtained by}

a. Gross observation made at post-mortem examination

b. Number of injuries

c. Entrance and exit wounds,

d. Dimension of wounds

e. Area affected or site of the wounds

f. Track of the wounds, bodily structures and organs involved

g. Frequency of involvement of body parts

h. Type and number of missile recovered

i. Nature of immediate effects,

j. Nature of delayed effects

k. Fatal period

a. External post-mortem findings

l. Internal post-mortem findings 
3. The following medicolegal aspects of the cases were noted from the history, examination of inquest reports and other connected paper, from gross observation made at post-mortem examination.

a. Whether the firearm and explosive injuries were ante-mortem or post mortem in nature

b. How many times the deceased was shot

c. Which one of the injuries were fatal

d. The range of firing

e. Type of weapon used in firing

f. Fatal period: how long the victim survived after receiving the injury

g. Contribution of associated injuries to the fatal effects

h. Cause of death as revealed at post-mortem examination

The various data regarding the cases collected by the methods as mentioned above were compiled using standard proforma and were then stu died and analysed.

The results obtained from the study have been presented as under the observation.

OBSERVATION AND RESULTS: In the present study, a total of 100 cases of homicide by firearm and explosives drawn from the medicolegal autopsies of Varanasi area including Chandauli carried out in the mortuary of Department of Forensic Medicine of Institute of Medical Sciences, Banaras Hindu university, Varanasi, During the period from 1.7.99 to 30.11 .2000 (17 months).

\begin{tabular}{|l|c|}
\hline Types of firearms and explosive & Percentage \\
\hline Shotgun & 40 \\
\hline Rifle & 14 \\
\hline Revolver & 12 \\
\hline Pistol & 10 \\
\hline AK-47 & 2 \\
\hline Country made firearms & 21 \\
\hline Country made bombs & 12 \\
\hline \multicolumn{2}{|c|}{$\begin{array}{l}\text { Table 1: types of firearms and } \\
\text { explosives used for homicide. }\end{array}$} \\
\hline
\end{tabular}

Table given above on types of firearms and explosive used for homicide shows that in max $40 \%$ victims shot gun was used followed by country made firearms $21 \%$, rifel $14 \%$, revolver $12 \%$,bombs $12 \%$, Pistol was used in $10 \%$ and a AK47 rifle was used in $2 \%$ Victims.

\begin{tabular}{|c|c|}
\hline Medical aid & Percentage \\
\hline Not hospitalized & 77 \\
\hline $\begin{array}{l}\text { Hospitalized but not } \\
\text { operated }\end{array}$ & 13 \\
\hline Hospitalized and operated & 10 \\
\hline $\begin{array}{c}\text { Table 2: Medical aid received by the victim } \\
\text { of homicide by firearm and explosives. }\end{array}$ \\
\hline
\end{tabular}

The table given above clearly shows that over majority $77 \%$ of victims were not hospitalized. Very less no of victims 13\% were hospitalized but not operated.Few Victims 10\% were hospitalized and operated. 


\begin{tabular}{|c|c|}
\hline Place of death & Percentage \\
\hline Scene of crime & 55 \\
\hline Hospital & 23 \\
\hline On way to hospital & 5 \\
\hline Not known & 17 \\
\hline
\end{tabular}

Table 3: Place of death of victims of

homicide by firearms and explosives.
Table given above shows that over majority $55 \%$ of victims died at the scene of crime followed by $23 \%$ Victims who died following admission into the hospital. Only few 5\% victims died on way to the hospital. In $17 \%$ victims place of death could not be known.

\begin{tabular}{|c|c|}
\hline Survival period & Percentage \\
\hline Instantaneous & 43 \\
\hline Within one hour & 13 \\
\hline 1 hr to $6 \mathrm{hr}$ & 6 \\
\hline $6 \mathrm{hr}$ to $24 \mathrm{hr}$. & 3 \\
\hline More then $24 \mathrm{hr}$. & 18 \\
\hline Could not be known & 17 \\
\hline
\end{tabular}

Table 4: Survival period of victims of homicide by firearms and explosive.

\begin{tabular}{|l|c|}
\hline \multicolumn{1}{|c|}{ Causes of death } & Percentage \\
\hline $\begin{array}{l}\text { Instantaneous death due to } \\
\text { injuries ti vital organ (s) }\end{array}$ & 43 \\
\hline Shock and haemorrhage & 25 \\
\hline Septicemia & 14 \\
\hline Coma & 12 \\
\hline Blast Lungs & 4 \\
\hline $\begin{array}{l}\text { Asphyxia (Aspiration of } \\
\text { blood) }\end{array}$ & 2 \\
\hline \multicolumn{2}{|c|}{ Table 5: Causes of death in } \\
homicide by firearm and explosives. \\
\hline
\end{tabular}

Table given above on numbers of weapon used in homicidal firearm victims clearly shows that in max no $61.36 \%$ of victims, single weapon was used followed by use of double weapon in $14.78 \%$ and in vary few victims $4.54 \%$ more than two weapon were used. However, in $19.31 \%$ victims it could not be known.
Table on causes of death in homicide by firearms and explosives shows that max $43 \%$ victims died instantaneously due to injuries to vital organ (s) followed by death due to shock and haemorrhage $25 \%$, septicaemia $14 \%$,Coma $12 \%$,blast lungs $4 \%$ and asphyxia due to aspiration of blood in the respiratory tract.

\begin{tabular}{|c|c|c|}
\hline No of weapon & Numbers & Percentage \\
\hline Single & 54 & 61.36 \\
\hline Double & 13 & 14.78 \\
\hline More than two & 4 & 4.54 \\
\hline Not known & 17 & 19.31 \\
\hline \multicolumn{3}{|c|}{ Table 6: Numbers of firearm weapons } \\
used in homicidal firearm victims. \\
\hline
\end{tabular}




\begin{tabular}{|l|c|c|}
\hline \multicolumn{1}{|c|}{ Location } & Numbers & Percentage \\
\hline Head & 36 & 40.90 \\
\hline Neck & 2 & 2.27 \\
\hline Chest & 24 & 27.27 \\
\hline Abdomen & 7 & 7.95 \\
\hline Upper extremity & 2 & 2.27 \\
\hline Lower Extremity & 1 & 1.13 \\
\hline Multiple body parts & 41 & 46.59 \\
\hline
\end{tabular}

Table given above shows that max $46.59 \%$ victim, location of entry wound was on multiple body parts followed by on head $40.90 \%$, chest $27.27 \%$, abdomen $7.95 \%$, neck $2.27 \%$,Upper extremity $2.27 \%$, lower extremity $1.13 \%$.

Table 7: Situation of entry wounds on different body parts of the homicidal fire arm Victims.

The above table reveals that majority $53.40 \%$ of the victims had one entry wound followed by two in $15.90 \%$, three in $11.36 \%$, and more then Three $19.31 \%$.

\begin{tabular}{|c|c|c|}
\hline No Of entry wounds & Numbers & Percentage \\
\hline One & 47 & 53.40 \\
\hline Two & 14 & 15.90 \\
\hline Three & 10 & 11.36 \\
\hline More then three & 17 & 19.31 \\
\hline & $\begin{array}{c}\text { Table 8: Numbers of entrance wounds on } \\
\text { the body of homicide firearms victim. }\end{array}$ \\
\hline
\end{tabular}

\begin{tabular}{|c|c|c|}
\hline Range & Numbers & Percentage \\
\hline Contact & 26 & 29.54 \\
\hline Close/Near & 36 & 40.90 \\
\hline Distant & 18 & 20.45 \\
\hline Combination of near and distant & 8 & 9.09 \\
\hline \multicolumn{2}{|c|}{ Table 9: Range of fire on homicidal Victims } \\
\hline
\end{tabular}

Table given above on range of firearm discharge clearly depict that max no of victims $40.90 \%$ of homicide by firearm were shot at from close/Near range. This was followed by contract wound in $29.54 \%$ and distant range in 20.45 $\%$.Combination of near and distant range was seen in $9.09 \%$.

\begin{tabular}{|c|c|c|}
\hline Associated injuries & Numbers & Percentage \\
\hline Absent & 66 & 75 \\
\hline Present and fatal & 2 & 2.27 \\
\hline Present but not fatal & 20 & 22.75 \\
\hline
\end{tabular}

Table 10: Incidence of associated fatal and non fatal injuries by other weapons than firearms.

Table above shows that in three fourth $75 \%$ victims there were no associated injuries by any weapon other than firearm. In only $2(2.27 \%)$ Victims associated fatal injuries were present. However, in as many as 20 (22.75\%) victims associated injuries by other weapons were resent by they were not fatal.

DISCISSION: For the present study, a total of 100 cases of homicide by firearms and explosives were taken from the medicolegal autopsies of Varanasi area that were carried out in the mortuary of department of forensic medicine, Institute of medical sciences, Banaras Hindu University, Varanasi during the period from $1^{\text {st }}$ July 1999 to $30^{\text {th }}$ Nov 2000. These were stu died and analyzed with special reference to their medicolegal aspects. 
Types of Firearms and Explosive Used for Homicide: In the present study (Table 1) shotgun took the highest toll of lives (40\%) followed by country made firearms (21\%) rifle (14\%) revolver (12\%) Pistol (10\%) and AK 47 (2\%) rifle and country made bombs claimed (12\%) lives.

Fattech et al (1974) in USA found either $0.22 \%$ caliber pistol or rifle or 12 bore shot gun to be the most commonly used weapons for homicidal purpose in their series of 1,006 victims. Frequency of using either pistol or rifle in $22.8 \%$ cases, pistols in 19.2 shotguns in $15.3 \%$ and rifles in $7.5 \%$ cases of their series. Country made and musket were not used in any of their cases.

Shotgun took the highest tolls (50.56\%) also in the series of Gupta et al. (1979) as in the present study while country made guns were used in only $4.49 \%$ of their cases. Rifles (13.48\%), revolvers (12.23\%), pistols (5.61\%) and musket (3.37\%) were used with a relatively greater frequency in the series of Gupta et al. (1979) as compared to $14 \%, 12 \%$ and $10 \%, 0.00 \%$ respectively in our series.

In Nabachandra's series too, shotgun took highest toll of lives (45.12\%), followed by the country made guns (30.49\%), they two together claiming $75.61 \%$ of the total victims while revolver, pistols and mu skets alone claimed 7.32\%, 3.66\% and $1.23 \%$ lives, respectively. When more than one weapon was used for attacks on single victim, revolver or pistol with country made guns were commonly used together in $2(2.44 \%)$ cases and rifle, revolver and muskets combined were used in $7(8.53 \%)$ cases.

Medical Aid Received by Victims: In our study (Table 22) over majority of victims (77\%) could not be hospitalized and died either at the scene of crime or on way to hospital. Only small number of victims (13\%) could be hospitalized but could not be operated upon. However, few victims (10\%) were hospitalized and operated upon also.

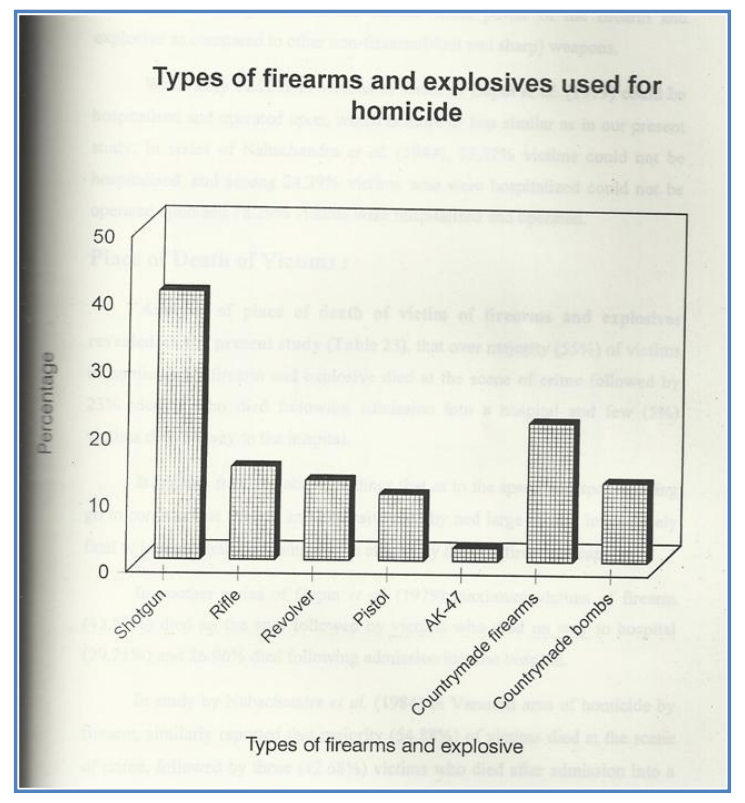

These findings confirm the serious lethal power of the firearm and explosive as compared to other non-firearm (blunt and sharp) weapons.

While only $11.23 \%$ of victims in series of Gupta et al. (1979) could be hospitalized and operated upon, which is more or less similar as in our present study. In series of Nabachandra et al. (1984) 57.32\% victims could not be hospitalized, and among $24.39 \%$ victims who were hospitalized could not be operated upon and 18.29\% victims were hospitalized and operated.

Place of Death of Victims: Analysis of place of death of victim of firearm and explosives revealed, in the present study (Table 23), That over majority (55\%) of victims of homicide by firearm and explosive died at the scene of crime followed by $23 \%$ victims who died following admission into a hospital and few (5\%) victims died on way to the hospital. 
It appears from the above findings that as to the speed and spot of dying go to confirm that firearm and explosives are by the large mostly immediately fatal to human victim as compared to attacks by the non firearm weapons.

In another series of Gupta et al. (1979) maximum victims of firearm (43.83\%) died on the spot followed by victims who died on way to hospital $(29.21 \%)$ and $26.96 \%$ died following admission into the hospital.

In study by Nabachandra et al. (1984) in Varanasi area of homicide by firearm, similarly reported that majority (54.88\%) of victims died at the scene of crime followed by those (42.68\%) victims who died after admission into a hospitals. Very few victims in series of Nabachandra et al. (1984) died on way to hospital (2.44\%) resembling closely to the figure (5\%) in present series.

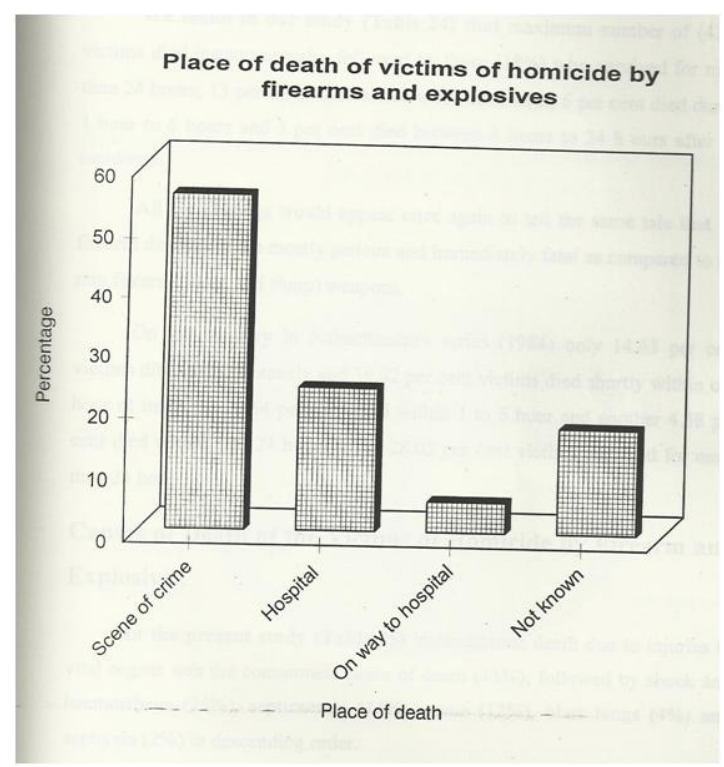

Survival Period of Victims of Homicide By Firearms and Explosive: 'We found in our study (Table 24) that maximum number of (43\%) victims died instantaneously, followed by those (18\%) who survived for more than 24 hours, 13 per cent victims died within one hour, 6 per cent died during 1 hour to 6 hours and 3 per cent died between 6 hours to 24 hours after the incidence.

All the findings would appear once again to tell the same tale that the firearm discharges are mostly serious and immediately fatal as compared to the non fiream (blunt and sharp) weapons.

On the contrary in Nabachandra's series (1984) only 14.63 per cent victims died instantaneously and 39.02 per cent victims died shortly within one hour of incidence, 8.54 per cent died within 1 to 6 hour and another 4.38 per cent died within 6 to 24 hours while 28.05 per cent victims survived for more than 24 hours.

Causes of Death of the Victims of Homicide by Firearm and Explosive: In the present study (Table 25) instantaneous death due to injuries to vital organs was the commonest cause of death (43\%), followed by shock and haemorrhage (25\%), septicaemia (14\%), coma (12\%), blast lungs (4\%) and asphyxia (2\%) in descending order.

In our study the most common cause of death of victims was instantaneous death due to injuries of vital organs. This could be attributed to the fact that along with firearms fatalities and 
explosives death were also included in our study. As in the present study coma took a fair toll of lives $(12 \%)$ in the series of Nabachandra it was doubly frequently $(24.7 \%)$.
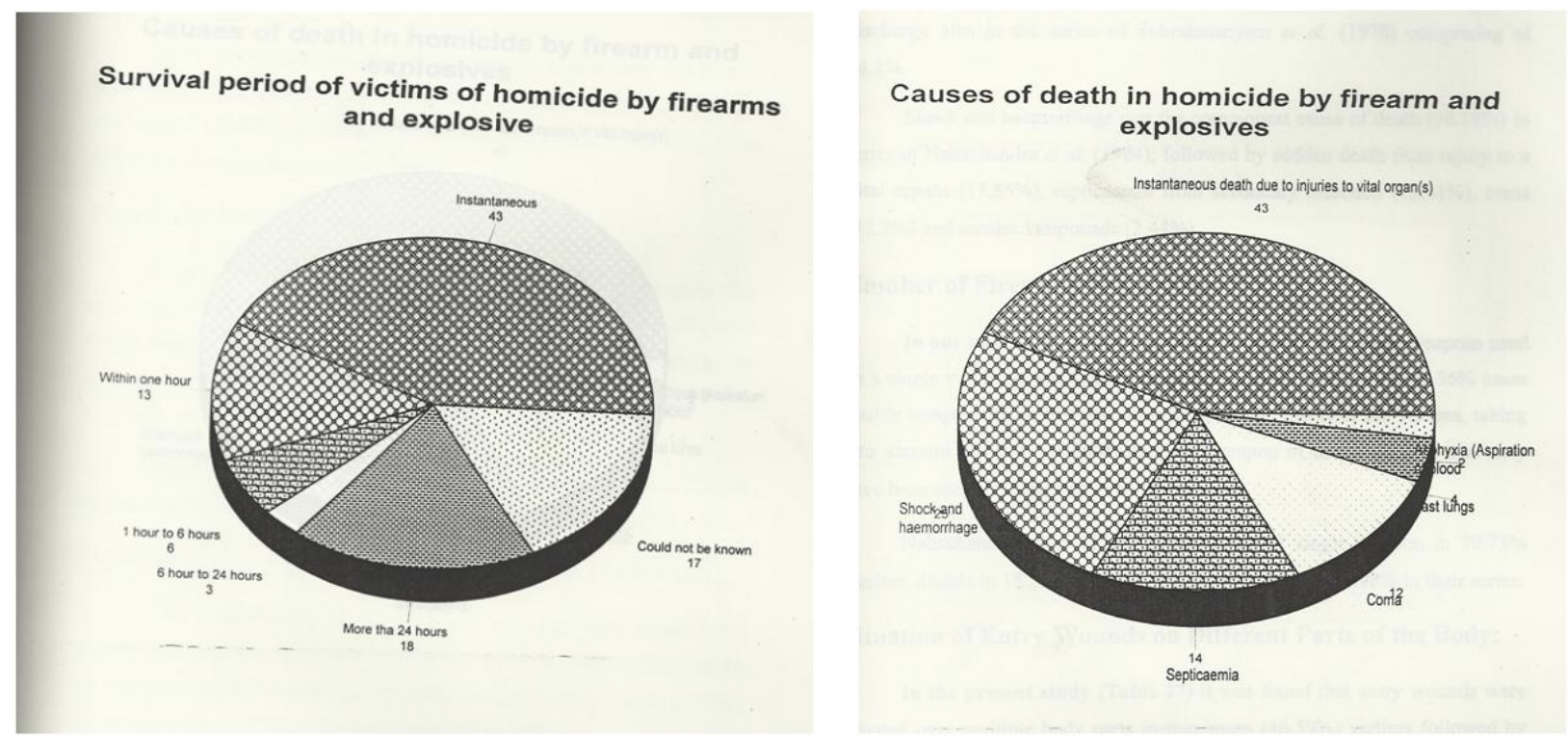

Shock and haemorrhage was the commonest cause of death (75.28\%) also in the series of Gupta et al. (1979), followed by injury to a vital organs (10.10\%). Shock and haemorrhage was the most common cause of deaths from firearm discharge also in the series of Subrahmanyam et al. (1978) comprising of

$94.2 \%$.

Shock and haemorrhage was the commonest cause of death (56.10\%) in series of Nabachandra et al. (1984); followed by sudden death from injury to a vital organs (15.85\%), septicaemia from secondary infection (13.41\%), coma (12.2\%) and cardiac tamponade (2.44\%).

Number of Firearm Weapons Used: In our study (Table 26) regarding the number of firearm weapons used on a single victim, it was found that single weapon was used in $61.36 \%$ cases double weapons in $14.78 \%$ and more than two in $5.54 \%$ of the victims, taking into account the fact that more than one weapon of the same kind also may have been used in single victim.

Nabachandra et al. (1984) reported use of single weapon in $70.73 \%$ o victims, double in $18.29 \%$ ) and more than two weapon in $10.98 \%$ in their series.

Situation of Entry Wounds on Different Parts of the Body: In the present study (Table 27) it was found that entry wounds were situated over multiple body parts in maximum (46.59\%) victims followed by on head alone (40.90\%) over chest (27.27\%), abdomen (7.95\%), neck (2.27\%), upper extremities (2.27\%) and lower extremities (1.13\%).

Involvement of multiple body parts in a large number of cases $(46.59 \%)$ in our study indicate that the assailants in homicide frequently fire more than one shot involving multiple body parts of the victim. This is not so in cases of accidental and suicidal firearm discharges that are generally limited to a single discharge located only over one body part of the victim while two or more suicidal shots in the same case have been reported in rare cases (Glaister, 1973). 


\section{ORIGINAL ARTICLE}
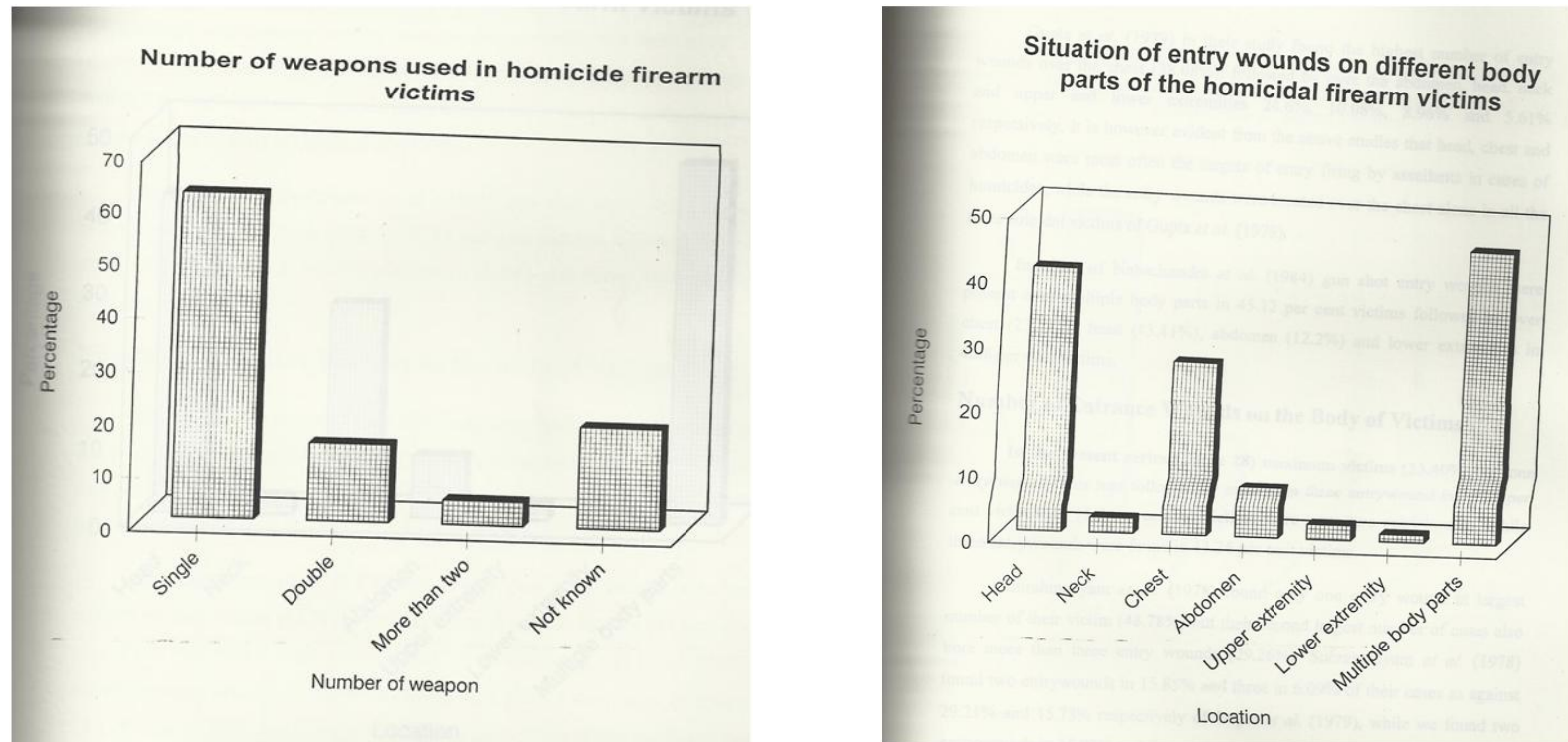

Gupta et al. (1979) in their study found the highest number of entry wounds over the chest (38.08\%), followed by over the abdomen, head, neck and upper and lower extremities $24.6 \%$, $10.08 \%, 8.96 \%$ and $5.61 \%$ respectively. It is however evident from the above studies that head, chest and abdomen were most often the targets of entry firing by assailants in cases of homicides, while the entry wounds were located over the chest alone in all the three suicidal victims of Gupta et al. (1979).

In series of Nabachandra et al. (1984) gun shot entry wounds were present over multiple body parts in 45.12 per cent victims followed by over chest (23.17\%), head (13.41\%), abdomen (12.2\%) and lower extremities in 4.88 per cent victims.

Number of Entrance Wounds on the Body of Victims: In the present series (Table 28) maximum victims (53.40\%) had one entry wound. This was followed by more than three entry wound in 19.31 per cent victims. In 15.9 per cent of victims there were two entry wounds, while three entry wounds were found in 11.36 per cent victims.

Subrahmanyam et al. (1978) found only one entry wound in largest number of their victim (48.78\%) but their second largest number of cases also bore more than three entry wounds (29.26\%). Subramanyam et al. (1978) found two entry wounds in $15.85 \%$ and three in $6.09 \%$ of their cases as against $29.21 \%$ and $15.73 \%$ respectively of Gupta et al. (1979), while we found two entry wounds in $15.90 \%$ and three entry wounds in $11.36 \%$ in our series.

\begin{tabular}{|c|c|c|c|c|c|c|}
\hline No. of entry wounds & $\begin{array}{c}\text { Subramanyam } \\
\text { et al }\end{array}$ & $\begin{array}{c}\text { Gupta } \\
\text { et al }\end{array}$ & $\begin{array}{c}\text { Nabachandra } \\
\text { et al. }\end{array}$ & Present series & Total & $\%$ \\
\hline One & 40 & 39 & 24 & 47 & 150 & $43.98 \mathrm{~J}$ \\
\hline Two & 13 & 26 & $\mathrm{u}^{5} \mathrm{~J}$ & 14 & $58 \wedge$ & 17 \\
\hline Three & 5 & 14 & 2 & 10 & 31 & 9.09 \\
\hline More than three & 24 & 10 & 51 & 17 & 102 & 29.91 \\
\hline & 82 & 89 & 82 & 88 & 341 & 100 \\
\hline
\end{tabular}




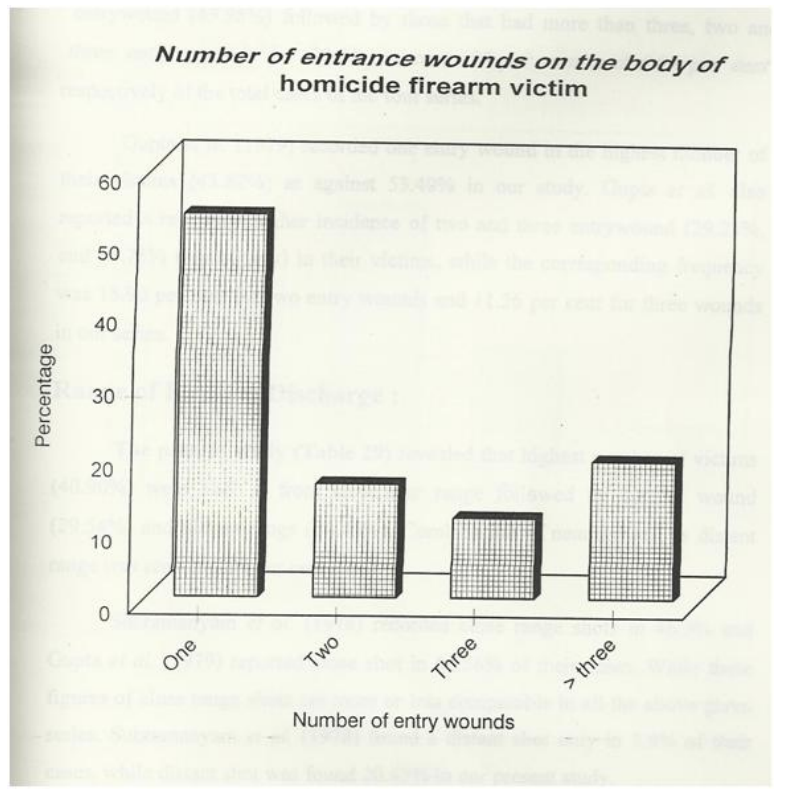

A composite analysis of the number of entry wounds in all the above four studies based on Varanasi area (in different periods) comprising a total of 341 cases goes to reveal that the largest number of victims had only one entry wound (43.98\%) followed by those that had more than three, two and three entry wounds i.e. 29.91 per cent, 17 per cent and 9.09 per cent respectively of the total cases of the four series.

Gupta et al. (1979) recorded one entry wound in the highest number of their victims (43.82\%) as against $53.40 \%$ in our study. Gupta et al. also reported a relatively higher incidence of two and three entry wound (29.21\%, and $15.73 \%$ respectively) in their victims, while the corresponding frequency was 15.90 per cent for two entry wounds and 11.36 per cent for three wounds in our series.

Range of Firearm Discharge: The present study (Table 29) revealed that highest number of victims (40.90\%) were shot at from close/near range followed by contact wound $(29.54 \%)$ and distant range $(20.45 \%)$. Combination of near as well as distant range was seen in 9.09 per cent cases.

Subramanyam et al. (1978) recorded close range shots in $46.3 \%$ and Gupta et al. (1979) reported close shot in 50.56\%) of their cases. While these figures of close range shots are more or less comparable in all the above given series, Subramanyam et al. (1978) found a distant shot only in $3.6 \%$ of their cases, while distant shot was found $20.45 \%$ in our present study.

Nabachandra et al. (1984) noted that the highest number of victims were shot form a distant range (45.12\%) followed by those shot from close or near range (36.59\%) and $12.19 \%$ of the victims were fired from a combination of near and distant range and the range of firing could not be reasonably ascertained in $6.10 \%$ of the cases. 


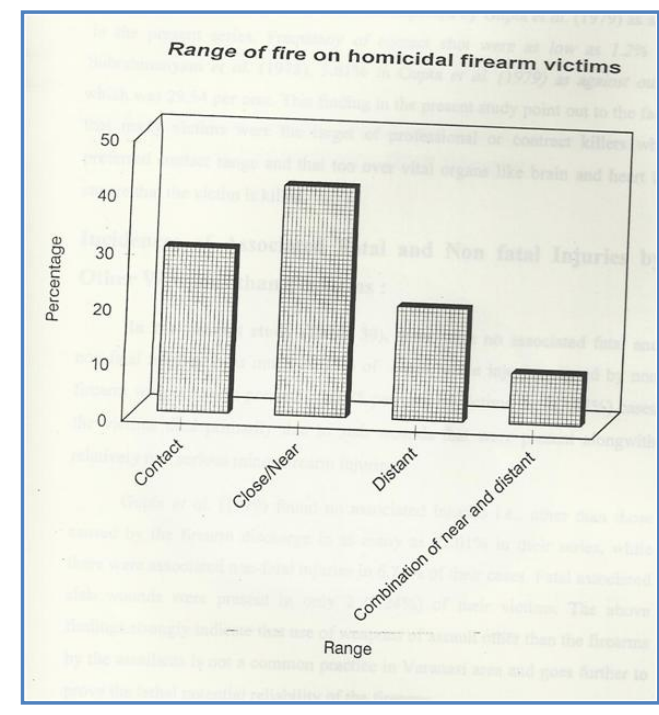

In this context it may be interesting to note that the range of firing remained unknown in as high as $48.8 \%$ of the cases of Subramanyam et al. (1928), while not a single such case was reported by Gupta et al. (1979) as also in the present series. Frequency of contact shot were as low as $1.2 \%$ in Subrahmanyam et al. (1978), 5.61\% in Gupta et al. (1979) as against ours which was 29.54 per cent. This finding in the present study point out to the fact that many victims were the target of professional or contract killers who preferred contact range and that too over vital organs like brain and heart to ensure that the victim is killed.

Incidences of Associated Fatal and Non fatal Injuries by Other Weapons than Firearms:

In the present study (Table 30), there were no associated fatal and non-fatal injuries in as much as $75 \%$ of cases, while injuries caused by non firearm weapons were present in 22.75 per cent of victims. In $2(2.27 \%)$ cases the victims died primarily due to stab wounds that were present along with relatively non serious minor firearm injuries.

Gupta et al. (1979) found no associated injuries i.e., other than those caused by the firearm discharge in as many as $91.01 \%$ in their series, while there were associated non-fatal injuries in $6.74 \%$ of their cases. Fatal associated slab wounds were present in only 2 (2.24\%) of their victims. The above findings strongly indicate that use of weapons of assault other than the firearms by the assailants is not a common practice in Varanasi area and goes further to prove the lethal potential reliability of the firearms.

\section{SUMMARY AND CONCLUSION:}

Summary: One hundred cases of homicide by firearm and explosive drawn from the medicolegal autopsies brought to the mortuary of Department of Forensic Medicine, Institute of Medical Sciences, Banaras Hindu University, Varanasi, U.P. India during the period from 1st July, 1999 to 30 ${ }^{\text {th }}$ November 2000, were studied for a detailed medicolegal analysis. The important highlighting findings of the study are summarized as under :

1. Shotguns were used in maximum cases (40\%) followed by rifle (14\%).

2. Over three fourth (77\%) of the victims of homicide by firearm and explosive could not be hospitalized as they died soon after homicidal attack.

3. In over majority of victims (55\%) place of death was at the scene of crime.

4. Instantaneous death occurred in maximum number (43\%) of cases followed by death within one hour (13\%).

5. In maximum number (43\%) of victims death was instantaneous due to injuries to vital organs followed by shock and hemorrhage (25\%).

6. In over majority (61.36\%) of victims of homicide by firearms single weapon were used.

7. In maximum number of victims (40.90\%) location of entry wound was on head 
followed by on chest (27.27\%),

8. Single entry wound was seen in over majority (53.40\%) of victims of homicide firearm deaths.

9. Maximum number of victims (40.90\%) of homicide by firearms were shot at from close/near range.

10. Associated injuries by weapons other than firearms were seen in as many as much 25 per cent victims of fatal firearm injuries.

CONCLUSION: There has been a phenomenal rise in the use of firearms and explosives for committing various crimes lea ding to death of victims.

The ever expanding areas of individual and mass violence including communal violence, dacoities, smuggling across the international and state borders, kidnapping for ransom and hijacking of aircrafts have all contributed their share to the phenomenal rise in the use of firearm and explosives resulting in many homicidal fatalities. Hardly a day passes in the life of a Forensic Pathologist working in one of the autopsy centres mainly in the northern part of India including Varanasi area, where he/she is not required or called upon to perform medicolegal autopsy examination on a victims of alleged death from firearm discharge.

The present study based on Varanasi area has provided a number of revealing informations as summarized above regarding the homicidal firearm and explosive deaths, that are certainly going to be of much help to the Forensic pathologists and members of law enforcing agencies in understanding the medicolegal aspect of the homicidal firearm and explosive fatalities occurring in this part of the country. Further and more indepth studies using many more parameters over larger series of firearm and explosive death are strongly indicated.

\section{BIBLIOGRAPHY:}

1. Bhaskaran S. and Rao, D.R. (1969): Evaluation of Firearm Injuries and Deaths. Jr. hid. Acad. Fors. Sci., 8(2):99-104.

2. Blass D.C. and James R.C. (1978): Penetrating Wounds of the Neck and Upper Thorax. Jr. Trauma. 18(1):2-4.

3. Breitenecker R. (1969): Shotgun Wound Patterns. Am. J. Clin, Pathol. 52:258.

4. Bullock, H. (1955): Urban Homicide in Theory and Fact. Journal of Criminal Law and Criminology. 45:565-575.

5. Bureau of Police Research and Development (1983): Ministry of Home Affairs. Govt. of India, III.

6. Cameron, J.M. (1974): Changing Pattern of Violence. Med. Sci. Law. 13(4):264.

7. Cardarell, Albert P. (1968): An analysis of police killed by criminal action, 1961-63. Jr. Crim. Law and Criminology. 59(3):447-453.

8. Chandra, J., Dogra, T.D. and Dikshit, P.C. (1986): Comprehensive Study of Homicide in South Delhi.

9. Crime in India (1978): Bureau of Police Research and Development. Ministry of Home Affairs Government of India.

10. Crime of India (1979): Bureau of Police Research and Development, Ministry of Home Affairs, Govt, of India. 
11. Crime of India (1986): National Crime Records Bureau. Ministry of Home Affairs. Government of India.

12. Crime of India (1993): National Crime Records Bureau. Ministry of Home Affairs. Government of India.

13. Crime of India (1994): National Crime Records Bureau. Ministry of Home Affairs. Government of India.

14. Das Gupta S.M. and Tripathi C.B. (1983): A Study of the Homicide Cases Occurring in Varanasi Area. Indian Medical Gazette. CXVII (9):285-288.

15. Das Gupta S.M., Subramanyam B.V., Sarmah P.C. and Gupta A.K. (1979): Homicide by Multiple Firearms - Paper Presented at $1^{\text {st }}$ Annual Conference of Indian Association of Forensic Medicine.

16. Das Gupta, S.M. and Tripathi, C.B. (1983): A Study of the Homicide Cases Occurring in Varanasi Area. Indian Medical Gazette September, 1983. p. 285-288.

17. Das Gupta, S.M., Subsahmayan, B.V., Yadwad, B.S. and Kaviya, V.D. (1979): Trends in Homicide Journal of Indian Academy of Forensic Science. 18(1): 13.

18. Devasia, Leelamma and Devasia, V.V. (1989): Female Criminals and Female Victims, Nagpur: Dattsons.

19. Devasia, V.V. (1985): The Phenomenon of Criminal Homicide. Indian J. Criminology and Criminalistics, 12.

20. Devasia, V.V. and Devasia, L. (1985): The Phenomenon of Criminal Homicide. Indian J. Criminology and Criminalistics. 3-4:142-146.

21. Devasia, V.V. and Devasia, Leelamma (1982): "Sexual Behaviour of Male Prison Inmates Convicted of Criminal Hamicide". Indian J. Criminology and Criminalistics. 2-4:192-196.

22. Devasia, V.V. and Devasia, Leelamma (1984): Victims Offender Relationship in Female Homicide by Male : A Study Conducted in Maharashtra. Indian J. Soc.Work.XLV(3):317-324.

23. Fatteh A. (1972): Homicidal Gunshot Wounds of Mouth. J. For. Sc. Sco. 12:347.

24. Fatteh A. (1973): Hand Book of Forensic Pathology, Lippincott Edn. pp. 97-130.

25. Pokorny Alex D. (1965): A Comparison of Homicide in the Two Cities. The Jr. of Crim. Law, Criminology and Police Science. 56(4):479-487.

26. Pokorny Alex D. (1965): Human Violence : A Comparison of Homicide, Aggravated Assult, Suicide and Attempted Suicide. The Jr. of Crim. Law, Criminology and Police Science. 56(4):488-497.

27. Pokorny, Alex D. (1965). A Comparison of Homicide in Two Cities. The Jl. of Criminal Law Criminology and Police Sci. 56(4):479-487.

28. Poison C.J. and Gee D.J. (1973): The Essential of Forensic Medicine. $3^{\text {rd }}$ Edn. Pergamon Press, pp. 204-260.

29. Pramley L.F., Mattingly T.W. and Manion W.C. (1958): Penetrating Wounds of Heart an Sorts. Circulation. 17:953.

30. Rai, S.P. (1987): Thesis Submitted for A Study of Homicide by Blunt Violent in Medicolegal Autopsy.

31. Rajan V.N. and Krishna K.P. (1981): Victims of Homicide. The Indian Jr. of Criminology and Criminalisation, Vol. I, No. 4, Institute of Criminology and Forensic Science, Ministry of Home Affairs, Govt, of India, pp. 154-158. 
32. Rao I.B., Jauhari M. and Supanekar N.M. (1965): Firearms and Firearms Injuries. Published by Intelligence Bureau, Ministry of Home Affairs, Govt, of India, New Delhi.

33. Rao P.K. and Bhaskar G.B. (1972): Scorching in Firearm Injuries Report of a Case. Jr. Indian Acad. For. Sci. 11(2):39.

34. Reddy, K.S.N. (1982): Text Book of Essential of Forensic Medicine. Kothari Publishers, Bombay.

35. Richard Block (1975) : Homicide in Chicago A Nine Year Study (1965-1973). The Jl. of Criminal Law Criminology. 66(4):496-510.

36. Roy Kishor Kumar (1994): Study of Medico Legal Aspects of Homicide in Varanasi. M.D. Thesis.

37. Rudich M.D. et. al. (1978): Survival Following a Gunshot Wound of Abdominal Sorta and Inferior Vona Cava. Jr. Trauma. 18:548.

38. Rushforth N.H., Ford A.B. and Hirsh N. (1977): Violent Death in Metropolitan Country Changing Pattern of Homicides New England. J. Med. 297(10):538.

39. Saharan, D.V., Tripathi, A.K., Chandrika, J. and Dogra, T.D. (1988): A Study of Murder in South Delhi. FMT. 5(3-4):12-15.

40. Subrahmanyam, B.V., Das Gupta, S.M., Rao, CM. and Kavita, V.D. (1978): Epidemiological Firearm Fatalities Jl. Indian Acad. Fer. Sci. 17:1.

41. Subramanyam B.V., Das Gupta S.M. and Gupta A.K. (1978): Unusual Firearm Fatalities - Paper Presented at the $2^{\text {nd }}$ Annual Conference of Indian Academy of Forensic Medicine.

42. Taylor's Principles and Practice of Medical Jurisprudence $12^{\text {th }}$ Edn. Edited by Simpson K., 1965 J \& A Churchill Ltd. pp. 282-315.

\section{AUTHORS:}

1. Rajeev Kumar

\section{PARTICULARS OF CONTRIBUTORS:}

1. Professor \& Head, Department of Forensic Medicine \& Toxicology, Gold Field Ins titute of Medical Sciences \& Research, Chhainsa, Ballabgarh, Faridabad.

\section{NAME ADDRESS EMAIL ID OF THE} CORRESPONDING AUTHOR:

Dr. Rajeev Kumar,

Professor,

House No. - 877, 2nd Floor,

Sector - 40, Gurgaon, PIN - 122001.

Email - rajeevkyam@gmail.com

Date of Submission: 24/09/2013.

Date of Peer Review: 04/10/2013.

Date of Acceptance: 22/10/2013.

Date of Publishing: 29/10/2013 